\title{
Insurance Business in Economic Development in Pematangsiantar City
}

DOI: https://doi.org/10.47175/rissj.v3i1.394

\section{| Parlin Dony Sipayung |}

Faculty of Law, Universitas Simalungun, Indonesia parlindonysipayungralyn@gmail. com

\begin{abstract}
The development of economic potential such as the insurance business needs to be carried out efficiently through careful planning so that the insurance economic resources owned can be used continuously and passed on to generations in Pematangsiantar city. How positive expectations from the insurance business as an insurance business in Pematangsiantar City form an agreement that binds the insurance agreement What obstacles are faced by the cause of the insurance business in Pematangsiantar in economic development. The positive expectation from the insurance business can be transformed into an insurance business, which means entering premiums which then become funds. Funds stored for a period of time in an insurance company can be used by the company to finance a business that is profitable for them in addition to helping the community increase their businesses by providing capital or credit for the short and long term. All of these efforts have clearly helped economic development in the Republic of Indonesia. The form of the insurance agreement is a standard agreement or "standard contract" where the agreement whose contents are standardized and stated in the form of a form. The obstacles in the practice of insurance business in Pematangsiantar City are when the customer pays less attention to and understands the conditions specified in the standard agreement before the agreement held.

KEYWORDS

insurance business; economy; Pematangsiantar
\end{abstract}

\section{INTRODUCTION}

According to the nature of nature, humans everywhere and at any age always live together, live in groups. At least this life together can be seen from two people, husband and wife or mother and baby. In the history of human development there is no one who lives alone, separated from other human groups, except in circumstances of necessity and even then only temporarily. That's why humans as creatures basically always want to hang out and gather with other human beings, so they are creatures who like to socialize. Aristotle said that humans are zoon politicons (social beings) (Utrecht, 1979). Humans as social beings cannot be separated or cannot stand alone but help each other to help each other so that things do not happen that harm one party, it is necessary to make something, for example through agreements. Agreements are an important thing from legal institutions. which is aa in society, in this case we can see clearly that there are legal actions indirectly legal actions already exist in society, so that some legal objects occur in society, which is an agreement. is an agreement by which one party binds himself to do something that has been previously 
agreed upon. So the agreement is very important in social life, because the agreement is the efforts of humans in social life to be able to meet their needs, either in the form of goods or in the form of services, in order to meet their needs in life.

Seeing developments in the field of business, which is accompanied by the development of science and the application of technological results, this is no longer balanced with human development to meet their needs. With the development of the business world and the development of the business world and the development of the application of technological results in all fields in the midst of an increasingly and complex society so as to meet the needs of an increasingly dynamic and practical society, it is necessary to make arrangements regarding rights and obligations if they enter into legal relations, namely between entrepreneurs or creditors and consumers or debtors to carry out unilateral agreements or with the term standard (standard) agreement.

The unilateral or standard agreement is implemented and prepared first unilaterally, because of the need to use it repeatedly and regularly for similar legal acts. Thus, it is necessary to hold standardized forms of agreement letters and print them in large amounts of turnover in the form of blanks or forms. This can make it easier for the community to implement or enter into practical agreements. So developments in the economic world have caused many forms related to legal relations to occur which in their realization can show that the main role in determining the terms of the relationship will be held or determined by only one party, namely the party in a stronger position. the economy.

We can clearly see that with the issuance of various regulations that were born from standard or standard agreements which sometimes directly or indirectly regulate various conditions and legal actions of a mass nature, which are used for each consumer or customer with one another. The law has determined the procedures and conditions that must be met at the time of entering into an agreement, while the community only participates in realizing it in other forms, so there is a possibility that the fulfillment of the conditions contained in the law will result in deviations from occurring. deviations in carrying out an actual agreement, however, it turns out that the legal relationship through an agreement still occurs and must be fulfilled what is the subject of the agreement.

Then if we look at the provisions or principles of the agreement, namely the existence of a principle of contractual freedom, where according to this principle, people are free to carry out the contents or conditions of the agreement as long as they do not conflict with the law and morality. Whereas in the standard agreement, the content and terms of the agreement are always determined by only one party, which is then offered to the public who are their customers. One of these companies is an insurance business. Thus it appears that the agreement is an agreement carried out by both parties, where the customer will submit to what they have agreed with the insurance company, and carry out everything that is the obligation of the customer and so on. also from the insurance company, and carry out everything that is the obligation of the customer and also from the insurance company the right to receive what is the customer's obligation and vice versa what the customer is entitled to will be given by the insurance company.

\section{RESEARCH METHODS}

Any data to be collected in a study, obtained through certain methods, from certain sources and by using certain tools or instruments. a statement that shows the distance between expectations and reality, between plans and implementation, between and sollen and das sein (Ronny, 1988). a proposition that is considered not to be a real argument, because it still has to be tested or proven in future research (Soekanto, 1984). That research is a way of progress (Sapari 2007). Therefore, a method is needed to conduct research. 2 methods 
are used, namely: Library research which is carried out by collecting library materials sourced from written books, writings and from articles that are in accordance with the title of this thesis. Field Research (Field Research) which is done by conducting interviews, observations and other matters to data sources or respondents who know insurance problems.

\section{RESULTS AND DISCUSSION}

\section{Definition and Object of Insurance}

The word "Insurance" is often interpreted or equated with the term "Insurance". In Dutch it is called "verzekering" which means that there are two parties involved in a legal relationship, namely that one is able to bear or guarantee that the other party will receive compensation for a loss that may be suffered as a result of an event that was not necessarily going to happen. or earlier it cannot be determined when it will occur. As a Tegen Achievement (Reciprocal) the insured party is required to pay a certain amount of money to the party who bears it. The money however becomes the property and rights of the party who bears it even after the insurance ends the event in question occurs. According to article 246 of the KUHD, explaining that coverage or insurance is an agreement between two parties in an agreement where one party by receiving an amount of money called the "Premium" burdens himself with an agreement that he will bear the loss, damage or loss of the expected profit, which may be suffered. second party due to an unspecified event (Onzeker Vooral). If we look more carefully at Article 246 of the Commercial Code above, it can be concluded that the insurance agreement is a reciprocal agreement, meaning an agreement in which both parties each have an equivalent obligation. In this case, the insured has the obligation to pay the premium, the amount of which is determined by the insurer, while the insurer has the obligation to compensate for the loss suffered by the insured. So it is not a free agreement as stated in Article 1314 of the Civil Code.

The insurance agreement includes a possibility agreement (Kans Overenskomst) which means an agreement that contains an element of possibility because of the insurer's obligation to compensate for losses on whether or not certain events arise. The above classification in chapter XV, precisely can be seen in article 1774 of the Civil Code which reads as follows: "A chance agreement is an act whose results are about the profit and loss for both parties and while the parties depend on an event that is not certain."

Such are insurance agreements, life insurance interest, gambling and betting". So, specifically, Article 1774 of the Civil Code mentions:

a. The meaning of the word luck

b. Three examples of such agreements are:

- Insurance

- One's life fork flower

- Gambling and betting.

According to Wirjono Prodjodikoro (1986), the mention of the three examples above is correct, but the mention of the meaning is not precise, because there it is said that the implementation of the agreement in the form of profit or loss depends on events that do not necessarily occur this is because the insurer must compensate for the losses suffered by the insured. it depends on the presence or absence of indeterminate events (Onzeker Voorval). If the event occurs, then the insured suffers a loss as a result of which the insurer must compensate the insured loss. If the uncertain event does not exist, then the insurer does not need to replace anything that means profit for the insurer. 
According to H.M.N. Purwosutjipto, the inclusion of an insurance agreement in the gambling and betting group (Article 1774 of the Civil Code) is inappropriate, because there are striking differences between the two groups.

The agreements are:

a. Whereas in the insurance agreement, the relationship between the possibility of profit and loss and the indeterminate event can still be calculated or estimated if the probability of the occurrence of an uncertain event is greater, the insurer may refuse coverage or increase the premium.

b. In gambling or betting the relationship between the possibility of profit and loss with uncertain events cannot be calculated or estimated. The existence of profit and loss completely depends on the fate of the person who gambles or bets. (Purwosutjipto, 1986)

When examined in practice, this insurance agreement cannot be classified as a chancy agreement even though the agreement depends on uncertain events, this is based on the following reasons:

1. The transfer of risk is balanced with a premium in the insurance agreement, the transfer of risk from the insured to the insurer is balanced with premium payments by the insured which is balanced with the risk even though it is not agreed upon by the parties that the possibility of achievement is not balanced, while in a chancy agreement the parties intentionally doing chancy actions that are not dependent on balanced performance.

2. The element of interest is an absolute requirement. In the insurance agreement, the element of interest is an absolute requirement that must exist on the insured with the threat of canceling the insurance if there is no interest. Meanwhile, in a chancy agreement, the element of interest does not exist.

3. Can be sued before a court, while a chancy agreement if one of the parties defaults cannot be sued before a court. (Abdulkadir, 1978)

Thus insurance or coverage is a risk transfer agreement, whereby the insurer takes the insured's risk and as a performance contract, the insured is obliged to pay a premium to the insurer. The risk is in the form of a loss burden on the insured object against the dangers that may arise. Viewed from this angle, the insurer takes over the insured's risk, which means that the insurer binds himself to compensate the insured's loss in the event of an event (event that does not become a reality that befalls) that befalls the insured object and harms the insured.

\section{Types of Insurance}

There are many types of insurance that we know today, so for the purposes of this paper, the author needs to review the classification or classification of insurance obtained from various sources into three types, namely;

\section{Loss Insurance}

In this type of insurance that the purpose of loss coverage is to replace the losses incurred on the property of the insured. In this case the insured wants to protect the interests of the assets.

"The insurer is a reciprocal agreement between the insurer and the insured binding himself to pay the premium, while the insurer binds himself to provide compensation for the damage, loss or loss of expected profits that he may suffer due to an uncertain event."

From the definition above, it can be concluded, among others, as follows:

1. In loss coverage there are only two parties, namely the insurer and the insured. 
2. In the case of insurance, the losses incurred are goods that may be attacked by danger, which is detrimental to the insured. This item is an insured item.

3. In the case of loss coverage, the interest of the insurer's performance is to compensate for the actual loss suffered by the insured.

4. In the case of loss, the interest is a subjective right or obligation that is worth money, can be overwritten by danger and is not prohibited by law

5. Uncertain events in the form of loss insurance are indeterminate events that cause losses to the insured

6. In the case of loss insurance, the principle of identity is used in compensating for losses, meaning that only losses in compensation that are actually suffered by the insured are being replaced. (Emmy, 1980)

The coverage that includes loss coverage is:

a. Coverage against fire hazard

b. Coverage against dangers at sea

c. Coverage against the dangers of land and inland water transportation and others

2. Insurance Amount

In addition to loss coverage, it is also known that the compensation provided by the insurer cannot actually be said to be a substitute for losses because receiving compensation does not receive real compensation, in accordance with the losses suffered. The compensation given is actually the result of determining a certain amount agreed upon by the parties.

In the literature this coverage is often known as "Insurance of a sum of money (Simmen Verzekering). (Santoso, 1969) This type of insurance includes life insurance. Life insurance is a reciprocal agreement between the insurance cover (taker) and the insurer, whereby the insurance binds itself during the course of the coverage to pay premiums to the insurer as a direct result of the death of the person whose life is insured or the agreed period has passed. certain money to the person designated by the insurance cover as the beneficiary, clearly as follows:

a. The cover or insurance taker is a party to the insurance agreement who binds himself to pay premiums regularly to the insurer as a result he has a policy.

b. The insured body is the person whose life is insured, may also be the insurance cover itself and may also be another person appointed by the insurance cover.

c. The connoisseur may be the insurance cover itself and the heirs or it may be another person appointed by the insurance cover.

If in life insurance we mention parties in a narrow sense, then the parties meant here are the insurance takers and the insurers. However, if we give parties in a broad sense, then what is meant is not only the insurance taker and the insurer but also to other people who are needed for the insurance agreement and those who get the rights from the agreement. The parties must also be distinguished from people because someone may hold more than one function, for example, someone can function or be domiciled as an insurance taker and also as an insured or function as a guide or a beneficiary.

In that sense, the parties to life insurance are:

a. Insurer

Insurers are parties who bind themselves to pay a certain amount of money, the amount of which has been determined in such a way as to be appointed.

b. Insurance Taker or Insurance Cover

Insurance taker or insurance cover is the party who closes the life insurance agreement with the insurer who will bind himself to pay premiums regularly to the insurer. 
c. designated

Appointed is a person appointed by the insurance taker as the person entitled to receive compensation in the form of a certain amount of money from the insurer. In this case the insurance cover can designate itself as designated. So this appointment is located as a third party with an interest in accordance with what is meant in Article 1317 paragraph 2 of the Civil Code.

From the explanation above, it can be concluded that there are several differences between loss insurance and life insurance which can be seen from several aspects:

a. In terms of goal

Loss insurance aims to replace losses that may arise on the insured's property, due to the occurrence of uncertain events. While life insurance aims to pay a certain amount of money, it does not depend on whether the uncertain event causes a loss or not.

b. In terms of the parties involved

In loss insurance there are only two parties involved, namely the insurer and the insured. While life insurance, the insured can function as an insurance cover or insurance taker and as an appointed.

c. Insured aspect

In loss insurance, what is insured is goods or objects that may harm the insured, called the insured object (Verzekerd Voorverp). Meanwhile, what is insured in life insurance is the life or life of someone called the insured.

d. In terms of performance of the guarantor

In loss insurance, the insurer is to compensate for the loss actually suffered by the insured, while in life insurance it is to pay a certain amount of money that has been determined at the time of closing and does not depend on whether there is a loss or not.

e. In terms of interest

In the interest loss coverage are rights and obligations that can be valued in money, can be threatened with harm and are not prohibited by law. Meanwhile, the interest in life insurance is immaterial and usually takes the form of a family relationship.

f. Evenemen

Events in loss insurance are in the form of the occurrence of uncertain events that cause the insured. While the event in life insurance is the loss of a person's life or the passage of the agreed period without the death of the insured (not an event that causes a loss).

g. Identity principle

The meaning of the loss principle is that only losses that are actually suffered by the insured will be reimbursed. This principle only applies to loss coverage and does not apply to life insurance, because the material element in this life insurance is not an absolute element.

\section{Mixed Insurance}

Mixed coverage "is sum coverage mixed with loss coverage, for example coverage.

There are two types of performance accident coverage for the insurer:

a. If an accident causes permanent disability, for example the loss of one eye, an accident. In the event that the insured loses one eye, the insurer is obliged to pay $30 \%$ of the total insured.

b. Meanwhile, if you lose both eyes, the insured will receive the full amount $(100 \%$ of the sum insured).

From the description above, it is clear that accident coverage contains two mixed elements, namely elements of loss coverage (doctor's fees, hospital treatment and 
medicines) and total coverage (permanent disability, loss of hands, eyes, feet, ears, fingers and others).

\section{Insurance Policy and Premium}

In article 255 of the Commercial Code it is determined that, an insurance agreement must be made in writing in a deed called a policy. As stated in the previous descriptions, the policy is proof of the existence of an insurance agreement but is not an element of the insurance agreement. According to the law, the policy must be made by the insured, submitted to the insurer for signature. Within 24 hours, the insurer must return the policy to the insured after it has been signed (article 259 of the Commercial Code).

In practice, insurance companies have compiled their respective policy forms with certain conditions. In order to prevent unfair competition, insurance companies are trying to make the policy terms uniform so that a stark difference between one insurance company and another can be avoided. This uniformity is aimed primarily at certain types of insurance, so that national standard policies are established.

According to the conditions stipulated in the policy, there are three well-known types of policies, namely:

a. Airline Policy

Airline Policy is because this policy is created and issued by the Insurance Carrier. In the airline policy, in addition to the conditions determined by law, special provisions apply to the airline that issued it. Insurance companies that use this policy have experienced many difficulties in their operations so that gradually this policy is abandoned.

b. Stock Policy

It is said that the stock exchange policy is because this policy is used in insurance exchanges and is a policy with uniform forms and conditions. This policy uniformity effort arose in accordance with the experiences of the insurance company world which gradually became dissatisfied with the existence of various policies with different terms. Efforts to improve this are still being worked on and if there are additional conditions, these conditions are printed and given a policy number. If this condition has not been printed, usually the condition is attached to the policy concerned, that the condition also applies to the insurance. In Indonesia, we can see this policy uniformity effort in fire insurance and motor vehicle insurance policies that have been implemented by the Indonesian Insurance Council with uniform forms and conditions.

c. Lloyds Police

Lloyds policy is a policy used by the Lloyds London stock exchange. This policy was developed separately under the Lloyds brand and is used only by The Lloyds Corporation. This policy is used in fire insurance and insurance against other hazards. And in general the policy is only valid for a period of one year in accordance with Article 25 paragraph (2) of Marine Insurance of 1906, if it exceeds that period, the insurance is canceled. Classification of the Policy according to the nature of its validity, namely:

a. Travel Policy

It is called a travel policy because this policy is used for insurance of a trip that does not question the number of days or weeks of travel and the distance of the trip, but it is sufficient if the policy states that the trip is from, to, like. or the termination of the trip due to damage or circumstances that prevent the journey from continuing. With the completion of the trip, this insurance automatically ends.

b. Time Policy 
It is said to be a time policy because the usage is based on a certain time, for example a month, half a year and so on. The determination must be fixed on the date and time of the insurance starting on December 1, 1998 at 12.00 WIB, until May 31, 1999 at 12.00 WIB (6 months period).

Thus, Article 256 of the Commercial Code, in every policy except for life insurance, must contain the following:

a. The day the insurance agreement was made

b. The name of the person entering into the insurance agreement

c. A fairly clear description of the insured object

d. Insured Amount

e. The dangers borne by the insurer

$\mathrm{f}$. The insurance premium

g. All conditions that are important for the insurer to know

h. Insurer's signature

Apart from the conditions specified in Article 256 of the Commercial Code, insurance against hazards in land, river and inland water transportation, is added with the policy requirements as specified in Article 686 of the Commercial Code, namely:

1. The time in which the transportation journey must be completed, if that time is specified in the letter of carriage

2. Whether the transportation journey must be carried out continuously or can be stopped temporarily in the middle of the road.

3. The name of the captain of the ship, river or its driver or the coachman of the transportation vehicle, or the name of a carrier who undertakes the transportation.

From the descriptions above, the policy in an insurance serves as evidence that the coverage has occurred and as a basis for determining the rights and obligations of the parties in the agreement.

\section{Terms of the Validity of the Insurance Agreement}

Coverage is an agreement, therefore the conditions for the validity of an agreement also apply to coverage, as regulated in Article 1320 of the Civil Code, the special conditions stipulated in the Commercial Code are still valid.

\section{There is a hint of will}

Between these parties, there must be an agreement of will, meaning that both parties must agree on the terms of the agreement. What is approved by the insurer must also be approved by the insured. Thus there is a common understanding between the two parties regarding the objects that are the object of the agreement and regarding the conditions that apply to the agreement.

If we look at Article 257 paragraph 1 of the Commercial Code, we can see that the insurance agreement occurs immediately after a consensus agreement is reached between the insured and the insurer, the mutual rights and obligations of the insurer and the insured existed since then, even before the signing of the policy. Then the coverage that has been achieved with the approval of the will must be made in writing in a deed called a policy (article 251 paragraph 1 of the Commercial Code). ).

2. The authority to carry out legal actions

Both parties who carry out the insurance must be authorized to take legal actions, meaning that both parties are adults, not under pardon, not in memory impairment, not in a state of failure, in other words capable of acting according to the law. If the parties represent the other party holding the insurance, it is necessary to state for the purposes for whom he or she is providing the insurance. 
3. There is an insured object

In every insurance there must be objects that are insured. Therefore, the insured is the insured, then he must have a direct or indirect relationship with the insured object, it is called a direct relationship, if the insured has an interest in the object. The insured party must be able to prove that he really owns or has an interest in the insured object. If he is unable to prove it, it results in the assumption that he has no interest whatsoever, which causes the insurance to be void, the person who insures the object prohibited by law is deemed to have no interest, if it is also held then the insurance is void (Article 599 of the Commercial Code) In other words, the evidence of the object being insured must legally belong to the insured.

4. There are casuals that are allowed

What is meant by casual which is allowed here is that the contents of the insurance agreement are not prohibited by law, and do not conflict with public order, and do not conflict with decency.

5. Premium Payment

Insurance is a reciprocal agreement, so both parties must excel, the insurer accepts the risk transfer for the insured object, while the insured must pay a premium in return.

6. Obligation of Notice

The obligation to notify the insured, the insured must notify the insurer about the condition of the insured object. This obligation is carried out at the time of making the agreement, if the insured is negligent, the coverage is canceled (article 251 of the Commercial Code). The obligations as regulated in Article 251 of the Commercial Code are not suspended because of the good faith or not of the insured. If the insured mistakenly notifies, it will also result in the insurance being canceled, unless the parties have agreed otherwise. Usually this kind of coverage is explicitly stated in the notification policy.

\section{Positive Expectations from the Insurance Business in Pematangsiantar City}

Pematangsiantar City as the second largest city in North Sumatra after Medan has great potential to be developed in terms of the economy, especially in the insurance business. The velocity of money is a major factor in the process of economic development. The high and low velocity of money in an area will determine the level of economic progress itself. In line with the above, of course the City of Siantar expects the development or increase of investors in the insurance sector in the city of Pematangsiantar which at the same time educates the people of Pematangsiantar City to be able to utilize insurance companies both corporately and personally. There are several things that according to the author must be stated which are the roles and functions of insurance for Pematangsiantar community and entrepreneurs:

1. Insurance causes or keeps people and companies safe. By buying insurance, entrepreneurs or private people will have peace of mind. For example, goods in a shipment are protected from losses, someone will insure the goods on an insurance company (Shipping Insurance). By buying life insurance, the head of the family (father) will feel at ease and calm in guaranteeing their offspring in the future. If the father dies or is unable to earn a living for his children, there is a guarantee for the family.

2. With insurance, the efficiency of the company can be maintained in order to maintain the smooth running of the company, then by way of risk coverage can be reduced.

3. With insurance, there is a tendency, the withdrawal of fees will be carried out as fairly as possible, meaning that insurance costs must be fair according to the size of the risk 
insured. For example, in the life insurance of a very old person, the insurance is bigger and the insurance is younger. In a contract neither party can be harmed.

4. Insurance as the basis for purchasing credit

5. Insurance is a means of saving. In life insurance, currently we spend money, while its use is in the future. But unfortunately at the present time life insurance is less attractive because it is not very profitable for the community.

6. Insurance can be seen as part of a source of income. This source is based on financing the business. For example, the machines are seen technically how much production capacity is given by the machine. While humans how much income because it has its own expertise. Therefore, the skill is insured because if it is not insured, the loss will be so large in the event of an accident that interferes with the speed of the skill.

\section{Insurance Agreement Form}

In every insurance agreement, in fact the form of the agreement is standard in the sense that all forms of the agreement have been prepared by the insurance company to be presented to the prospective insured. This does not mean that this agreement is meant to impede the freedom of contract. As we know that in terms of freedom of contract, where everyone is generally allowed to freely choose to:

1. Implement or not carry out the agreement

2. Carry out an agreement with whom he wants.

3. Determine the content, validity and terms of an agreement.

In the law, the principle of freedom of contract is not expressly stated, but the whole law of this agreement in principle has an open nature. So as mentioned above that the standard agreement form at this time is very much found in the practice of daily life in the midst of society, especially in the economic field, this standard agreement is no longer a new thing but has become a necessity or a habit that is used, or habits that are used to speed up the implementation of daily activities.

If we see in practice that the implementation of standard agreements, where the party in this case the entrepreneur as the creditor has determined the content of the form and terms of the agreement. The debtor or customer who will and who has bound himself to the agreement and is obliged to carry out the provisions contained in the contents of the agreement. So that in this case we clearly see that the standard agreement limits the principle of freedom of contract. With the development of society, the application of the principle of freedom of contact is increasingly limited, we can see that there are more and more standard agreements arising in the midst of society, especially in the economic field.

In the field of economic traffic through stages where Kral Bucher divides these levels into three levels, namely:

1. Separate economic level

In terms of production and consumption are not separated, in other words, at this level there is absolutely no exchange of goods. Each person or family produces their own needs.

2. The level of the city's economy

At this level, exchange occurs, namely the direct exchange of goods with one another. At this time people do not produce all kinds of goods but concentrate their work on one particular field. If he needs the goods he produces are exchanged for other goods, the goods he produces are exchanged for what is needed.

3. The level of the nation's economy

With this level of economy, capital plays an important role in the economy. The hallmark of an economy like this is the use of money as an intermediary item that has 
the power within itself to exchange for all kinds of goods and services. (Manulang, 1982).

\section{Barriers Faced in Business Development in Pematangsiantar City}

After being described at length in previous chapters in the implementation of standard/standard agreements, the author sees that the implementation of the agreement in practice has many obstacles that can interfere with the smooth running of the insurance business. The people of Pematangsiantar city who want to have a legal relationship with the company that issued these regulations in general because they understand and understand the purpose and benefits of the effort to issue the regulation. The people of Pematangsiantar city who are bound by the agreement or the customer do not know the regulations in case of problems in the future, even though the company assumes that every customer has known the provisions since he became a customer.

The lack of fluency in treating this regulation is also due to the form and condition of the regulations that do not sufficiently meet the formal requirements so that they cannot be effectively enforced. This situation can be seen from the standard provisions and regulations which show that the regulations are rigid, where special conditions are left to the parties who can regulate them. The obstacles that are most often encountered are when the customer does not pay attention and understand the conditions that have been determined or stated in the regulation after he has bound himself to the agreement they did. In the insurance agreement there is often a misunderstanding, because the insurer in offering its services to the customer does not explain in detail the rights and obligations to the customer and the risks, so that when there is arrears for more than four months in premium payments and the insurance does not have a cash value, the coverage automatically becomes canceled and the insurer is not obliged to bear anything and the policy expires. Such a clause feels burdensome to the community, even the customers feel they cannot accept these requirements because they are not old and cannot receive their money back.

On the other hand, these standard regulations are listed in an easy-to-read place or in public places, so that people who wish to receive and carry out legal relations can easily research and study them so that unwanted things do not happen. Or vice versa, before the prospective customer declares his intention to become an insurance customer, the party or insurance officer explains correctly all the provisions to be implemented or the provisions set by the company. In relation to the principle of freedom of contract, in practice Bumi Putra Insurance should terminate the legal relationship that occurs between the party and the debtor's default after the insurance party fails to resolve it by way of deliberation. Deliberation in terms of contacting the debtor or giving proper warnings at least three times in a row in an official manner. In fact, the insurance company in Pematangsiantar is not found.

\section{CONCLUSION}

Insurance business problems in economic development have positive expectations from the insurance business that it can be transformed into an insurance business which means entering premiums which are then funds. Funds stored for a period of time in an insurance company can be used by the company to finance a business that is profitable for them in addition to helping the community increase their businesses by providing capital or credit for the short and long term. All of these efforts have clearly helped economic development in the Republic of Indonesia. The form of the insurance agreement is a standard agreement or "standard contract" where the agreement whose contents are standardized and stated in 
the form of a form. The obstacles in the practice of insurance business in Pematangsiantar City are when the customer pays less attention to and understands the conditions specified in the standard agreement before the agreement held. Need special education in schools / colleges about insurance. So that all students and students in the city of Pematangsiantar fully understand the existence of insurance in economic development in the city of Pematangsiantar. Thus, Pematangsiantar is expected to become the silk of the insurance business in North Sumatra. The standard contract remains valid because it has been signed by both parties, but it is recommended that a third party inform the prospective customer what their obligations are after signing the contract. Insurance companies must honestly provide explanations to prospective customers as long as the insurance company does not provide honest and comprehensive explanations about the substance of the agreement (policy). So because of natural law insurance companies have to go out of business for being dishonest. Pematangsiantar city government must play a role in front of providing counseling to insurance companies in order to promote insurance in business practices. Prospective companies and customers must sit on an equal footing under the guidance of the government for the continuation of the insurance agreement.

\section{REFERENCES}

Abdul Kadir Muhammad. (1978). Pokok-pokok Hukum Pertanggungan, Alumni Bandung

Abdul Kadir Muhammad. (1982). Hukum Perikatan, Penerbit Alumni Bandung.

Emmy Pangaribuan Simanjuntak (1980). Hukum Pertanggungan , Seksi Hukum Dagang Fakultas Hukum Universitas Gajah Mada, Yogyakarta.

H.M.N. Purwosutjipto. (1986). Pengertian Pokok-pokok Hukum Dagang Indonesia, Seri Hukum Pertanggungan Jilid 6, Djambatan, Jakarta.

Mariam Darus Badrulzaman. (1983). KUHPerdata Buku III Hukum Perikatan Dengan Penjelasan. Alumni, Bandung.

M. Yahya Harahap, SH. (1986). Segi-segi Hukum Perjanjian, Penerbit Alumni, Bandung.

M. Manullang. (1982). Pengantar Ekonomi Perusahaan, Penerbit Ghalia Indonesia, Jakarta.

Riduan Syahrani. (1989). Seluk Beluk dan Azas-azas Hukum Perdata, Penerbit Alumni, Bandung.

Ronny Hanitijo Somitro, SH. (1988). Metodologi Penelitian Hukum dan Jurimetri, Ghalia Indonesia.

Soerjono Soekanto. (1984). Pengantar Penelitian Hukum, UI - Pres, Jakarta

Santoso Peodjoe Soebroto. (1969). Hukum Pertanggungan Jiwa, Barata, Jakarta.

Sapari Imam Ashari, Drs. Suatu Petunjuk Praktik Metodologi Penelitian Sosial, Usaha Nasional, Surabaya.

Subekti, Hukum Perjanjian, Penerbit PT. Intermassa, Cetakan IX.

Subekti. (1989). Hukum Perjanjian, Penerbit Patrilineal. Intermassa, Jakarta.

Utrech. (1979). Pengantar Ilmu Hukum Di Indonesia, Jakarta.

Wirjono Prodjodikoro. (1986). Hukum Asuransi di Indonesia, PT. Intermasa, Jakarta. 